\title{
ELECTRICITY PRODUCTION FROM FOOD WASTE LEACHATE USING DOUBLE CHAMBER MICROBIAL FUEL CELL
}

\author{
Willie Prasidha ${ }^{1}$ and Akmal Irfan Majid ${ }^{1,2}$ \\ ${ }^{1}$ Faculty of Engineering, Universitas Gadjah Mada. \\ ${ }^{2}$ Center for Energy Studies, Universitas Gadjah Mada \\ Bulaksumur Caturtunggal Depok Sleman DIY 55281 \\ email: willie.p@ugm.ac.id
}

\begin{abstract}
This study was aimed at evaluating the performance of non-aerated and aerated double chamber microbial fuel cells from food waste leachate. The value of open circuit voltage (OCV) and close circuit voltage (CCV) were taken to analyze power density and current density of both configurations. Two double chamber microbial fuel cells (MFC) with different configurations were developed to produce electricity from food waste leachate and studied for 30 days. Anode and catode were made by uncoated carbon felt and graphite rod. Food waste and water were incubated inside a reactor. After 30 days, the electricity production characteristics between the two configurations were obtained. Both configurations reached the same maximum power density and maximum current density but the aerated MFC showed higher performance of maximum open-circuit voltage (OCV), average power density, and current density than nonaerated MFC. The results show that the supplying continuous dissolved air in the cathode chamber resulted in higher voltage, higher average power density, and higher average current density in double chamber microbial fuel cell.
\end{abstract}

Keywords: electricity production, microbial fuel cell, food waste leachate

\section{INTRODUCTION}

Food wastes are the largest component in municipal waste of urban area (Levis \& Barlaz, 2011) and it has the potential to produce energy. Most food wastes, generated from communities, restaurants and food factories, and end up in the landfill without any sustainable treatment. In fact, food waste can be used as a useful source of energy (Li, Cheng, Selvam, \& Wong, 2013). Nevertheless, the waste characteristics influence the selection of technology and waste management including how to convert the waste into a valuable form of energy (Sudibyo et al., 2017). Considering
Indonesia as the developing country and the $4^{\text {th }}$ most populous country in the world, understanding of a proper technology to manage the food wastes is essentially needed.

One type of food wastes is in liquid form, often called as the leachate. It is addressed by a complex structure and high pollutant (Levis \& Barlaz, 2011). Food leachate is formed from the hydrolysis or acidogenic stage of the anaerobic process of microorganisms that are rich of volatile fatty acids (Xu, Lam, Karthikeyan, \& Wong, 2011). Moreover, leachate can be obtained from food waste that contains many organic elements (Kang, Shin, \& 
Park, 2002) such as $\mathrm{NH}_{4}^{+}-\mathrm{N}$, heavy metals, organic and inorganic chlorine, salt, etc. Heavy pollutants from leachate can also contaminate water sources (Rikame, Mungray, \& Mungray, 2012). It adversely affects the health of the ecosystem.

A microbial fuel cell (MFC) is a bioelectrochemical system that can convert chemical energy to electrical energy contained in an organic substrate directly (Li, Ka, \& Wong, 2013) and it can be used as a solution to treat leachate food waste. MFC is one of the electrochemical technology to treat leachate and can produce clean energy (Rikame etal.,2012). It is effective to generate energy and decreases organic matter in leachate (Choi \& Ahn, 2015). There are two sides of the MFC, i.e. the anaerobic anode and the aerobic cathode, separated by an electrolyte membrane. In common principle of MFC, microbes play an important role as the oxidizing agent from the substrate in the anode side. Microbes oxidize the substrate which produces proton and electron. Here, electron is produced from microorganisms in the anode side which is then passed into the cathode through an external circuit. After that, an electrical energy is resulted and finally water is produced as the waste product. Since the waste product is harmless, MFC is an environmentally friendly method to produce power and a viable alternative for leachate treatment.
In principle, food waste leachate can be used as a substrate to produce electricity using MFC. One of the food waste products is acidic food waste leachate. Using aerated double chamber MFC, it could produce more electricity than using non-aerated one from acidogenic food waste leachate (Rikame $e t$ $a l ., 2012$ ). It was also reported by Greenman, Galvez, Giusti, and Ieropoulos (2009) that aerated MFC could produce more electricity than non-aerated MFC by using landfill leachate substrate. Even, MFC was not only producing electricity, but also could neutralize the acidity ( $\mathrm{pH}$ number) of the substrate from acidic to alkaline conditions (pH 4-9) according to Li et al. (2013).

The objective of this study was to evaluate the performance of non-aerated and aerated double chamber microbial fuel cells from food waste leachate. The value of open circuit voltage (OCV) and close circuit voltage (CCV) were taken to analyze power density and current density of both configurations.

\section{RESEARCH METHOD}

The food waste that containing fruit and vegetable wastes was collected and incubated inside an anaerobic reactor, illustrated in Figure 1.

The reactor had a single inlet on the top to insert food waste and water and single outlet in the bottom to collect the leachate. 


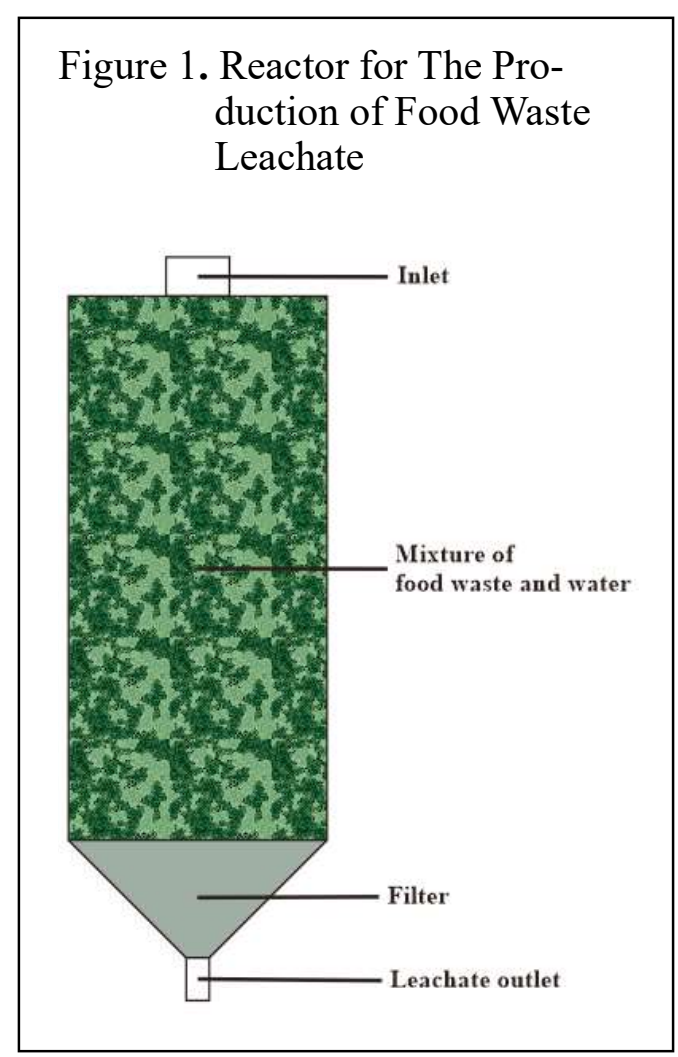

A filter was located in the reactor bottom (prior to the outlet) to result pure leachate. The food waste was submerged in the water for more than 30 days inside the reactor to produce proper leachate. After that, leachate was collected from the reactor outlet.

The two laboratory-scale double chamber MFC were used in this study. Those chambers were designed with capacity of $500 \mathrm{ml}$ working volume in each compartment and separated by a proton exchange membrane (PEM) of Nafion 212. The anode and cathode were constructed from rectangular carbon felt $(5 \mathrm{~cm}$ x $5 \mathrm{~cm}$ x 3 $\mathrm{mm}$ ) and 4 graphite rods (diameter $=10 \mathrm{~mm}$, length $=5 \mathrm{~cm}$ ) respectively. The effective area of the anode and cathode were $56 \mathrm{~cm}^{2}$ and $69 \mathrm{~cm}^{2}$ respectively. The electrodes were uncoated with any catalyst, thus cost of this MFC configuration was cheaper than the MFC with the coated electrode. The electrodes were submerged into the anode and cathode chambers.

Those devices were operated in 2 configurations: non-aerated and aerated. For both configurations, the electrodes were connected by a copper wire. A $100 \Omega$ of external resistance was used in the closedcircuit for CCV recording whereas for OCV recording, anode and cathode were not connected. The air pump was used to supply the dissolved air which contained oxygen in the cathode chamber (for the aerated MFC). The configuration of the aerated MFC is shown in Figure 2.

For both configurations, the anode chamber was fed with $500 \mathrm{ml}$ food waste leachate (as an anolyte) with $\mathrm{pH}$ of 7.1 and maintained to be in anaerobic condition. A $2 \mathrm{~g} / \mathrm{L}$ of sodium acetate $\left(\mathrm{CH}_{3} \mathrm{COONa}\right)$ solution was added into $500 \mathrm{ml}$ of catholyte in the cathode chamber and maintained to be in aerobic condition. Those microbial fuel cells were operated within 30 days. Results of OCV and CCV were recorded in every 24 hours. A digital multimeter was used to record OCV and CCV with $100 \Omega$ resistance. The electrical current (I) was calculated using Ohm's law of $\mathrm{I}=\mathrm{V} / \mathrm{R}$, where the voltage was 


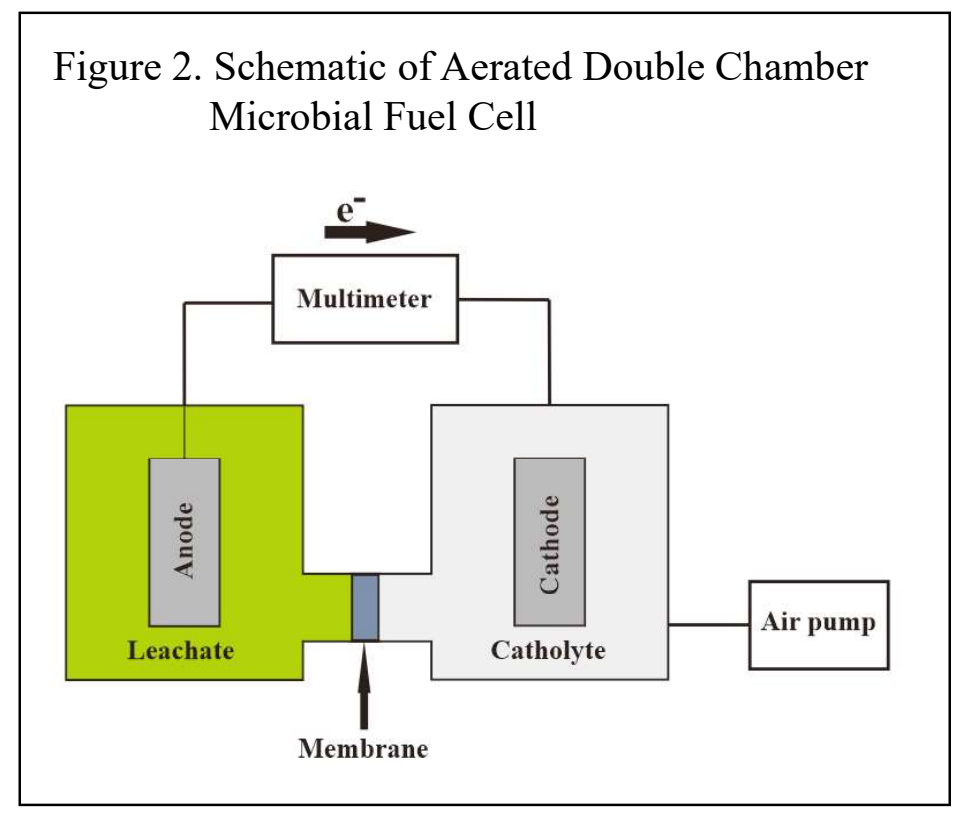

obtained from CCV and resistance of $100 \Omega$. The power $(\mathrm{P})$-in $\mathrm{mW}$, was calculated as $\mathrm{P}=$ $\mathrm{V} x \mathrm{I}$ and also power density (in $\mathrm{mW} / \mathrm{m}^{2}$ ) and current density (in $\mathrm{mA} / \mathrm{m}^{2}$ ) were calculated by dividing the obtained power and current by the surface area of the anode.

\section{RESULTS AND DISCUSSION}

The electricity from food waste leachate was resulted during the experimental period. The configurations were operated continuously for 30 days at open and closed circuit conditions. During the operation, the leachate condition was neutral.

Figure 3 shows OCV of both MFC configurations during the experiment. Close observation of the figure indicates that the maximum OCV (under no-load condition) is obtained at the $1^{\text {st }}$ day ( 24 hours after starting) of operation with $373 \mathrm{mV}$ for non-aerated
MFC. For aerated MFC, the maximum OCV was $404 \mathrm{mV}$, obtained at the $7^{\text {th }}$ day. It is also presented that the maximum microbial growth occurs at the $1^{\text {st }}$ day for non-aerated MFC and the $7^{\text {th }}$ day for aerated MFC. After the OCV reached maximum voltage at the $1^{\text {st }}$ day, the performance declines to be $-157 \mathrm{mV}$ at the $25^{\text {th }}$ day for non-aerated MFC. This phenomenon also points out the decrease of nutrient concentration in the feed. The negative phase starts to develop from the $20^{\text {th }}$ day and also shows the indication that the bacteria start to collapse (die) due to the exhaustion of nutrients. Conversely, the aerated MFC shows a slight decrease of OCV during the operation. The minimum OCV of aerated MFC was $146 \mathrm{mV}$.

Figure 4 presents that non-aerated MFC and aerated MFC have the same maximum current density of $21.4 \mathrm{~mA} / \mathrm{m}^{2}$ but it happens 
Electricity Production from Food Waste Leachate (Prasidha, W. \& Majid, A. I.)

Figure 3. Open Circuit Voltage of MFCs during Operation

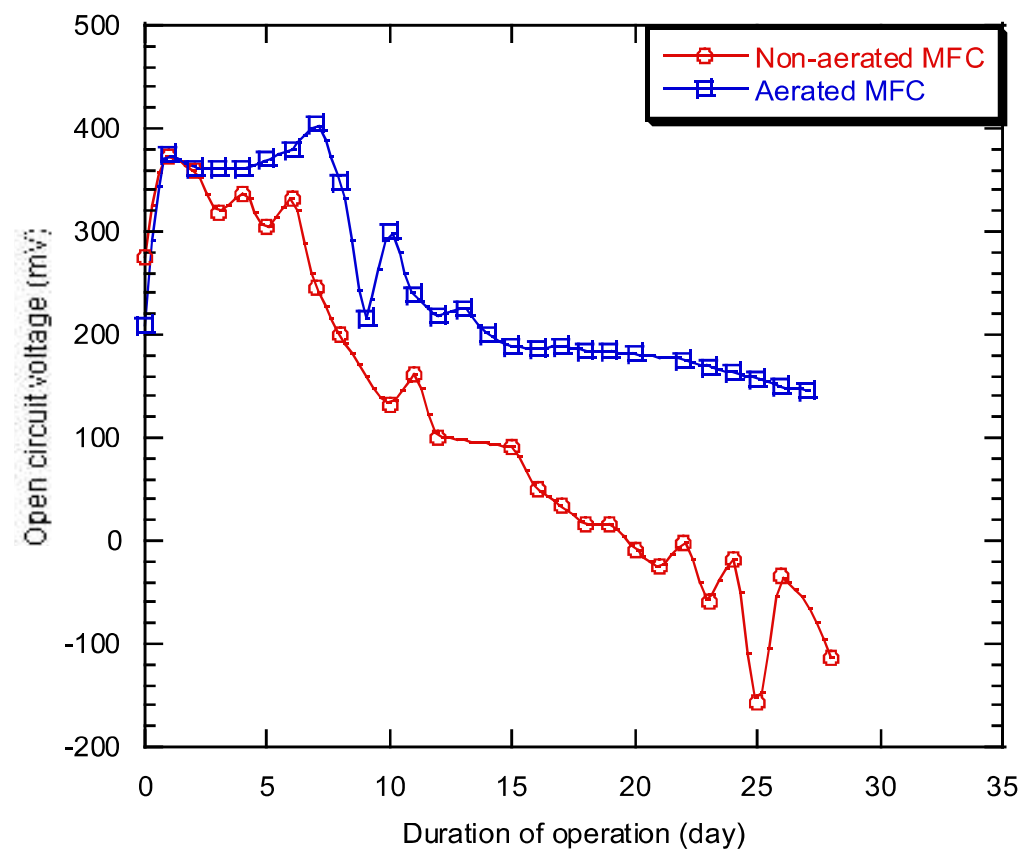

Figure 4. The Current Density of MFCs during Operation

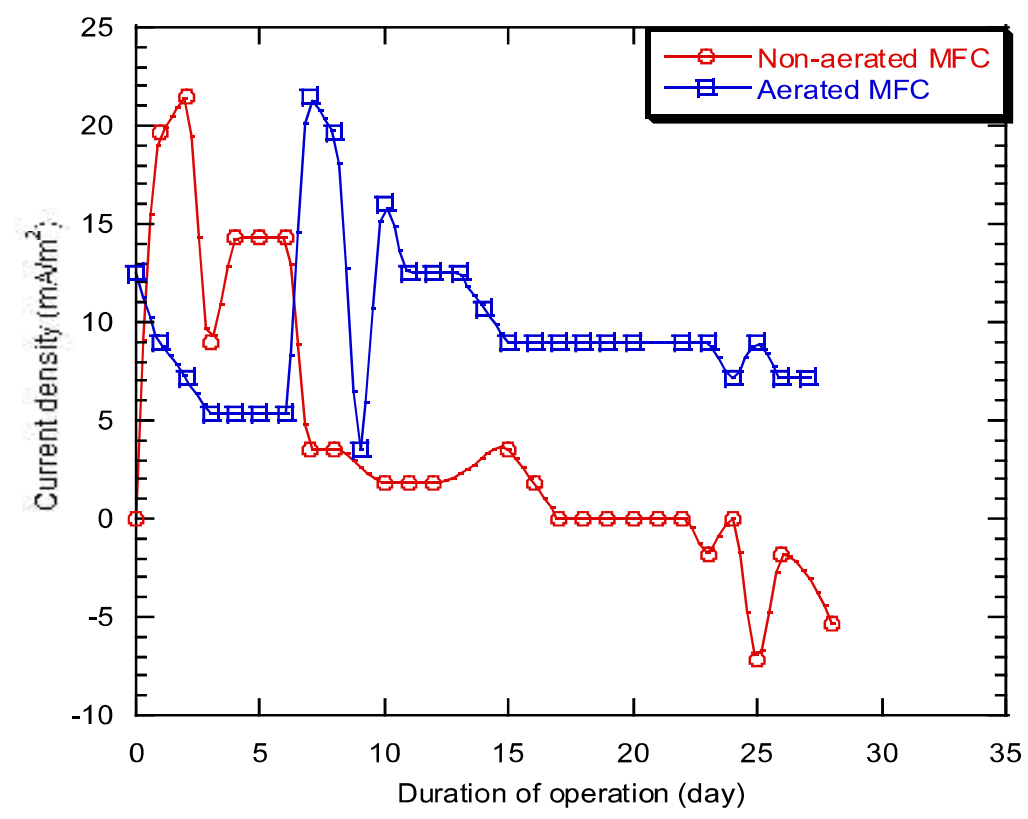


in different period. It can be stated that noth configurations have different characteristics of the current density curve. It is observed from the figure that the maximum current density of non-aerated MFC is obtained on $1^{\text {st }}$ day of operation while for the aerated MFC, the maximum current density was obtained on the $7^{\text {th }}$ day. Aerated MFC has a more stable current density than nonaerated MFC, indicated by a larger area under the curve that showed in Figure 4. The minimum current density of non-aerated MFC and aerated MFC are -5.3 mA and 7.1 $\mathrm{mA}$ respectively. For the non-aerated MFC, negative current density is achieved from the $23^{\text {th }}$ day of operation. Hence, it indicates that the bacteria start to collapse (die) in the anode chamber while the negative phase of current density was not obtained in the aerated MFC.

As shown in Figure 5, both of configurations have the same peak of power density that occur in the $2^{\text {nd }}$ day of operation for non-aerated MFC and the $7^{\text {th }}$ day for aerated MFC with value of 25.7 $\mathrm{mW} / \mathrm{m}^{2}$. From the viewpoint of average power density, aerated MFC has higher power density than non-aerated MFC where the average power density of nonaerated MFC and aerated MFC are $3.7 \mathrm{~mW} /$ $\mathrm{m}^{2}$ and $6.1 \mathrm{~mW} / \mathrm{m}^{2}$ respectively. When continuous dissolved oxygen was supplied at the cathode chamber of aerated MFC, the oxygen played an essential role as the

Figure 5. The Power Density of MFCs during Operation

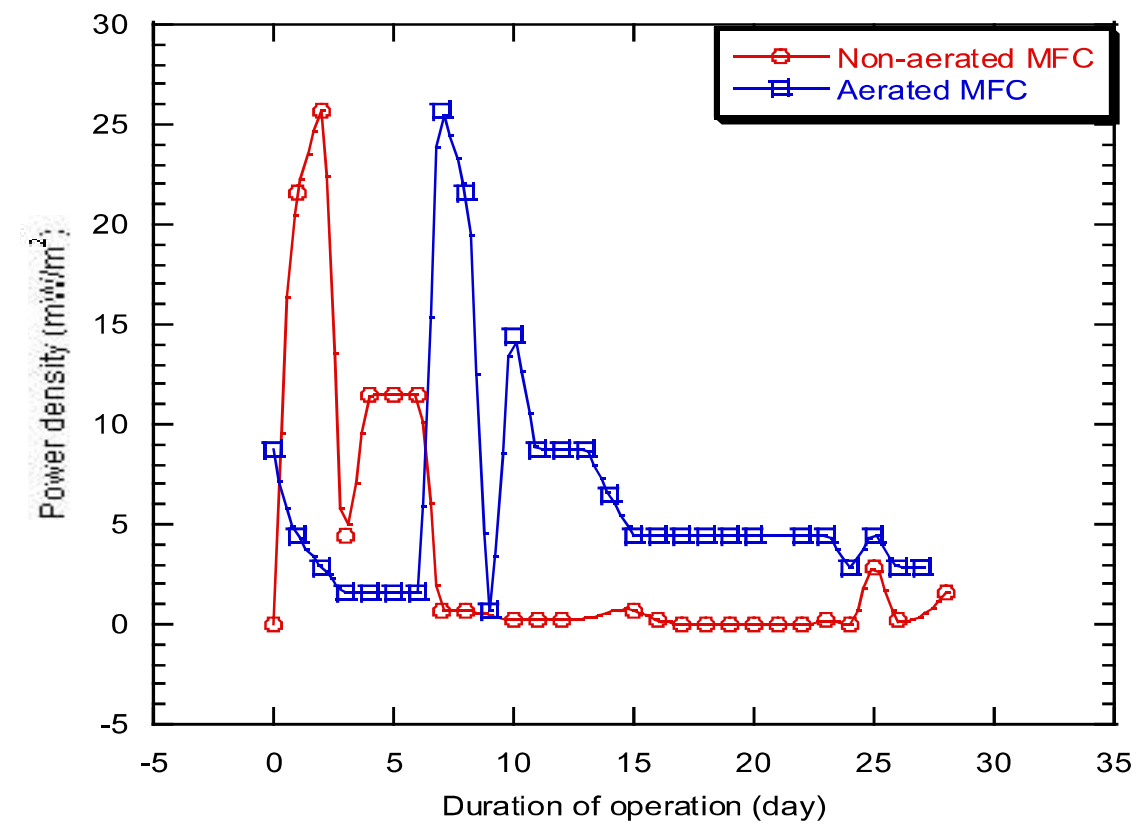


electron acceptor to improve the production of voltage and power density by promoting the electron and proton transfer rates. In addition, a more electron acceptors in the cathode chamber of aerated MFC was also obtained rather than in the cathode chamber of non-aerated MFC. Those above mentioned reasons led the production capacity of aerated MFC to be greater than non-aerated MFC. Besides, performing a good aeration system contributes to provide a sufficient dissolved oxygen supply for the microorganisms (Majid et al., 2016) even by controlling the oxygen-bubble size (Juwana et al., 2018; Majid et al., 2018).

\section{CONCLUSION}

An experimental study to investigate the electricity generation from food waste leachate (fruit waste and vegetable waste) was obtained under two configurations of double chamber microbial fuel cell. As a result, the aerated MFC showed higher performance of maximum $\mathrm{OCV}$ and average power density than non-aerated MFC. This study also proved that supplying dissolved air (oxygen) in the cathode chamber was able to increase the energy output of the double chamber microbial fuel cell.

\section{REFERENCES}

Choi, J., \& Ahn, Y. (2015). Enhanced bioelectricity harvesting in microbial fuel cells treating food waste leachate produced from biohydrogen fermentation. Bioresource Technology, 183,53-60.http://dx.doi.org/10.1016/j. biortech.2015.01.109.

Greenman, J., Galvez, A., Giusti, L., \& Ieropoulos, I. (2009). Electricity from landfill leachate using microbial fuel cells: Comparison with a biological aerated filter. Enzym and Microbial Technology, 44(2), 112-119. https://doi. org/10.1016/j.enzmictec.2008.09.012.

Kang, K., Shin, H., \& Park, H. (2002). Characterization of humic substances present in landfill leachates with different landfill ages and its implications. Water Research 36, 4023-4032. https://doi.org/10.1016/ S0043-1354(02)00114-8.

Levis, J. W., \& Barlaz, M. A. (2011). What is the most environmentally beneficial way to treat commercial food waste? Environmental Science \& Technology, 45(17), 7438-7444. https://doi. org/10.1021/es $103556 \mathrm{~m}$.

Li, X. M., Cheng, K. Y., Selvam, A., \& Wong, J. W. C. (2013). Bioelectricity production from acidic food waste leachate using microbial fuel cells: Effect of microbial inocula. Process Biochemistry, 48(2), 283288. http://dx.doi.org/10.1016/j. procbio.2012.10.001.

Li, X. M., Ka, Y. C., \& Wong, J. W. C. (2013). Bioelectricity production from food waste leachate using microbial fuel cells: Effect of $\mathrm{NaCl}$ and $\mathrm{pH}$. Bioresource Technology 149, 452458. http://dx.doi.org/10.1016/j. biortech.2013.09.037.

Juwana, W. E., Widyatama, A., Majid, A. I., Wiratni, Indarto, \& Deendarlianto. (2018). The application of digital image analysis to study the characteristic of bubble size distribution produced by orifice type microbubble generator. $A I P$ Conference Proceeding, 2001, 050004. https://doi.org/10.1063/1.5049995. 
Majid, A. I., Nugroho, F. M., Juwana, W. E., Budhijanto, W., Deendarlianto, \& Indarto. (2018). On the performance of venturi-porous pipe microbubble generator with inlet angle of $20^{\circ}$ and outlet angle of $12^{\circ}$. Dalam AIP Conference Proceeding 2001, 050009. https://doi.org/10.1063/1.5050000.

Majid, A. I., Aan, D., Wiratni, I., Brata, E. D., Purwono, B.A., \& Tontowi,A.E. (2016, Mei). Development of an industrialscale micro-bubble generator for the purposes of aerobic wastewater treatment. Makalah dipresentasikan dalam The International Conference on Multiphase Flow. Firenze, Italy. https://doi.org/10.13140/RG.2.1. 2618.5203.

Rikame, S. S., Mungray, A. A., \& Mungray, A. A. (2012). Electricity generation from acidogenic food waste leachate using dual chamber mediator less microbial fuel cell. International Biodeterioration \& Biodegradation 75, 131-137. http://dx.doi.org/10.1016/j. ibiod.2012.09.006.

Sudibyo, H., Majid, A. I., Pradana, Y. S., Wiratni B., Deendarlianto, \& Budiman, A. (2017). Technological evaluation of municipal solid waste management system in Indonesia. Energy Procedia, 105, 263-269. https://doi. org/10.1016/j.egypro.2017.03.312.

Xu, S. Y., Lam, H. P., Karthikeyan, O. P., \& Wong, J. W. (2011). Optimization of food waste hydrolysis in leach bed coupled with methanogenic reactor: effect of $\mathrm{pH}$ and bulking agent. Bioresource Technology, 102(4), 3702-3708. https://doi.org/10.1016/j. biortech.2010.11.095. 